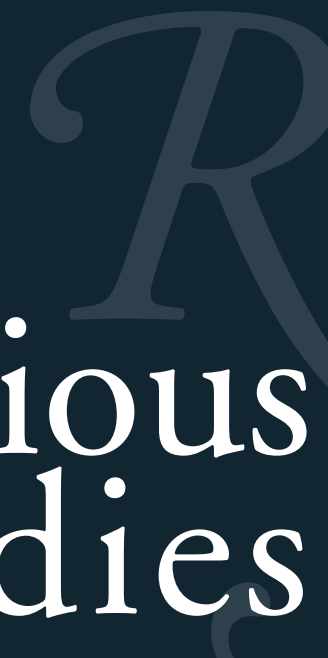

An international journal for
the philosophy of religion

EDITOR: ROBIN LE POIDEVIN

This issue includes articles by

Roi Benbassat, Mikel Burley, Travis Dumsday, Asle Eikrem, Ian James Kidd, Samuel Lebens, Atle Ottesen Søvik, Mikael Stenmark 


\section{Rẹligious Studies}

\author{
An international journal for \\ the philosophy of religion
}

Editor

ROBIN LE POIDEVIN

University of Leeds

Assistant Editor

MARK WYNN

University of Leeds

Book reviews editor

CLARE CARLISLE

King's College London

Emeritus Editors

PETER BYRNE

STEWART SUTHERLAND

KEITH WARD

\section{Editorial Board}

MEHDI AMINRAZAVI University of Mary Washington

PAMELA SUE ANDERSON Regent's Park College Oxford

DAVID BASINGER Roberts Wesleyan College

JOHN BISHOP University of Auckland

TIMOTHY CHAPPELL Open University

STEPHEN R. L. CLARK University of Liverpool

PAUL DRAPER Purdue University

JEROME GELLMAN Ben-Gurion University

CHRISTOPHER HAMILTON King's College London

VICTORIA HARRISON University of Glasgow

DANIEL HOWARD-SNYDER Western Washington University

JEFFREY JAMES JORDAN University of Delaware

BRIAN LEFTOW Oriel College Oxford

тімотну Mawson St Peter's College Oxford

TIM MCGREW Western Michigan University

WESLEY MORRISTON University of Colorado

MICHAEL MURRAY Templeton Foundation

YUJIN NAGASAWA University of Birmingham

MARK NELSON Westmont College

GRAHAM OPPY Monash University

KATHERIN ROGERS University of Delaware

TAMAR RUDAVSKY Ohio State University

JOHN SCHELLENBERG Mount Saint Vincent University

THOMAS SENOR University of Arkansas

RICHARD SWINBURNE Oriel College Oxford

THOMAS TALBOTT Willamette University

CHARLES TALIAFERro St Olaf College

EDWARD WIERENGA University of Rochester

Religious Studies is an international journal devoted to the problems of the philosophy of religion as these arise out of classical and contemporary discussions and from varied religious traditions. Space is devoted to articles, of which more than 25 are published each year, but the journal also contains a book review section, which may include review articles and shorter notes as well as normal-length reviews.

\section{Subscriptions}

Religious Studies (ISSN 0034-4125) is published four times a year in March, June, September and December. Four parts form a volume. The subscription price which includes delivery by air where appropriate, plus electronic access to institutional subscribers (but excluding VAT), of Volume 51 is $£ 316$ (USA $\$ 545$ in the USA, Canada and Mexico) for institutions and $£ 67$ (US \$110 in USA, Canada and Mexico) for individuals. Single parts are £86 (USA \$147 in USA, Canada and Mexico) plus postage. The electronic-only price available to institutional subscribers is £267 (\$469 in USA, Canada and Mexico). EU subscribers (outside the UK) who are not registered for VAT should add vaT at their country's rate. vaT-registered members should provide their vaT registration number. Japanese prices for institutions (including ASP delivery) are available from Kinokuniya Company Ltd, P.o. Box 55, Chitose, Tokyo 156, Japan. Orders, which must be accompanied by payment, may be sent to a bookseller, subscription agent or direct to the publisher: Cambridge University Press, Journals Fulfillment Department University Printing House, Shaftesbury Road, Cambridge св2 8BS, UK; or in the USA, Canada and Mexico: Cambridge University Press, Journals Fulfillment Department, 100 Brook Hill drive, West Nyack,

New York 10994 2133. Copies of the journal for subscribers in the USA, Canada and Mexico are sent by air to New York to arrive with minimum delay. Periodicals postage paid at New York, NY, and at additional mailing offices. Postmaster: send address changes in the USA Canada and Mexico to: Religious Studies, Cambridge University Press, 100 Brook Hill Drive, West Nyack, New York 10994-2133. Claims for missing issues should be made immediately on receipt of the subsequent issue.

\section{Copying}

This journal is registered with the Copyright Clearance Center, 222 Rosewood Drive, Danvers, MA 01923, USA (www.copyright. com). Organizations in the USA who are also registered with c.c.c. may therefore copy material (beyond the limits permitted by sections 107 and 108 of us copyright law) subject to payment to c.c.c. This consent does not extend to multiple copying for promotional or commercial purposes. IsI Tear Sheet Service, 3501 Market Street, Philadelphia, P.A. 19104, USA, is authorized to supply single copies of separate articles for private use only. Organizations authorized by the Copyright Licensing Agency may also copy material subject to the usual conditions. For all other use, permission should be sought from Cambridge or the American Branch of Cambridge University Press.

\section{Internet access}

Information on Religious Studies and all other Cambridge journals can be accessed via journals.cambridge.org.

This journal issue has been printed on FSC-certified paper and cover board. FSC is an independent, non-governmental, not-for-profit organization established to promote the responsible management of the world's forests. Please see www.fsc.org for information.

\section{(C) Cambridge University Press 2015}




\section{Religious \\ An international journal for the philosophy of religion}

\section{Articles}

RoI BenBASSAT Yeshayahu Leibowitz: Jewish existentialism [141-163]

IAN JAMES KIDD Nature, mystery, and morality: a Daoist view [165-181]

Samuel Lebens God and his imaginary friends: a Hassidic metaphysics [183-204]

Mikael Stenmark Competing conceptions of God: the personal God versus the God beyond being [205-220]

Mikel Burley Approaches to philosophy of religion: contemplating the world or trying to find our way home? [221-239]

Travis Dumsday Divine hiddenness and special revelation [241-259]

Atre Ottesen Søvik \& Asle Eikrem A critique of Samuel Shearn's moral critique of theodicies [261-270]

\section{Book reviews}

William Wood Blaise Pascal on Duplicity, Sin, and the Fall: The Secret Instinct (Kate KiRKPATRICK) [271-275]

Wendy Doniger On Hinduism (Jessica Frazier) [275-279] 